University of Wollongong

Research Online

Faculty of Commerce - Papers (Archive)

Faculty of Business and Law

$1-1-2007$

\title{
The institutional legacy and the development of an Australian national innovation system
}

Simon Ville

University of Wollongong, sville@uow.edu.au

Follow this and additional works at: https://ro.uow.edu.au/commpapers

Part of the Business Commons, and the Social and Behavioral Sciences Commons

\section{Recommended Citation}

Ville, Simon: The institutional legacy and the development of an Australian national innovation system 2007, 112-136.

https://ro.uow.edu.au/commpapers/580

Research Online is the open access institutional repository for the University of Wollongong. For further information contact the UOW Library: research-pubs@uow.edu.au 


\title{
The institutional legacy and the development of an Australian national innovation system
}

\author{
Abstract \\ Institutions are the rules of the game that help to shape the long-term historical development of societies. \\ They mediate human interaction and can be more or less formal (or tangible) in nature ranging from \\ systems of government to common modes of behaviour. Most formal institutions can be distinguished as \\ economic, social, political or cultural in nature although such distinctions are more difficult to make for \\ informal institutions. What is certain is the pervasive impact of all types of institutions on a country's \\ multifaceted development. Thus, economic performance may be shaped as much by a nation's legal \\ system as by its trade policy.

\section{Keywords} \\ innovation, system, institutional, legacy, national, australian, development

\section{Disciplines} \\ Business | Social and Behavioral Sciences

\section{Publication Details} \\ Ville, S. (2007). The institutional legacy and the development of an Australian national innovation system. \\ In W. R. Garside (Eds.), Institutions and Market Economies: The Political Economy of Growth and \\ Development (pp. 112-136). Basingstoke: Palgrave Macmillan.
}


The institutional legacy and the development of an

Australian national innovation system

Simon Ville

Introduction

Institutions are the rules of the game that help to shape the long-term historical development of societies. They mediate human interaction and can be more or less formal (or tangible) in nature ranging from systems of government to common modes of behaviour. Most formal institutions can be distinguished as economic, social, political or cultural in nature although such distinctions are more difficult to make for informal institutions. What is certain is the pervasive impact of all types of institutions on a country's multifaceted development. Thus, economic performance may be shaped as much by a nation's legal system as by its trade policy.

In this chapter we sketch the origins and development of institutions that have had a significant bearing upon innovation as one of the mainstays of the economic growth of Australia since White Settlement two centuries ago. Most existing studies of relevant Australian institutions have focused on the period since Federation, and little attempt has been made to analyse the institutions-economic development relationship. ${ }^{1}$ Our description of institutions and analysis of their bearing upon economic progress is underpinned by the new institutionalism, particularly that of Douglass North. North's contribution is most striking in his rejection of rational choice models and so-called efficiency theory: for him, a society's set of institutions 
evolve through a wide range of influences or ideologies, which rarely provide for an optimal economic outcome. $^{2}$

Institutions and economic change

North developed a dynamic theory of institutional change composed of three elements: informal 'constraints', formal 'constraints' and enforcement mechanisms. Both formal and informal institutions play a 'constraining' role in the sense that they bring some order to the chaos of human interactions. Informal constraints include norms of behaviour, conventions and codes of conduct. They are embodied in the belief systems, cultures and ideologies of a society that evolve gradually over long periods of time and have the ability to endure through major historical events. A continuum exists from informal to formal constraints, with the latter including the law, systems of government, public policy and economic markets. These can alter markedly over shorter time periods in response to major events and changes in the dominant actors.

More specifically, in the economic sphere institutions bring order to production and exchange, and it is their effect on the cost of exchange and production that largely explains their influence on economic performance. Thus, for example, a well-defined and respected system of property rights will encourage cost-reducing innovation by protecting the value of the rents associated with new ideas. Particular codes of conduct will be conducive to low transaction costs, thereby making exchange more efficient.

While the effect of institutions generally is to reduce uncertainty in human interaction, this does not inevitably provide the most efficient economic outcomes. 
North noted three reasons why suboptimality often results: our limited understanding of our own reality and how it changes over time; our imperfect belief systems; and our blunt tools for implementing change and development. As a result, North rather depressingly concluded: 'Economic history is an endless depressing tale of miscalculation leading to famine, starvation, deceit and warfare, death, economic stagnation and decline, and indeed the disappearance of whole civilizations' (North, 1999: 18). In this light, the economic enrichment of 'Western' nations over the last two centuries can be viewed as the exception rather than the rule, since most societies have failed to establish the institutional structure necessary for sustainable economic modernization.

Western exceptionalism is explained by North through adaptive efficiency: 'the ability of some societies to adjust flexibly in the face of shock and evolve institutions that effectively deal with altered reality' (North, 1999:18). Stable but unchanging institutions do not provide the impetus for economic growth. ${ }^{3}$ Rosenberg and Birdzell emphasize the role of institutional change in their explanation of 'How the West Grew Rich' (Rosenberg and Birdzell, 1986). They cite nine institutional innovations favourable to economic development in Western Europe by the eighteenth century, which cover a range of broad or specific legal, financial, religious and political contexts. These are: the legal enforcement of contracts and property claims; the evolution of bills of exchange and modern banking systems; insurance; the replacement of arbitrary confiscation with regular taxation and recognized property rights; economic association without kinship; double-entry bookkeeping; religious and moral systems conducive to commercial activity; the mercantilist partnership; and political fragmentation in Europe. 
Rosenberg and Birdzell's institutional innovations coalesce with North's thinking on adaptive institutions. A key aspect of modern economic development is the shift from personal to impersonal systems of exchange. Personal trade occurs on a small local scale with few players where monitoring is easy. A wider market may be possible where behaviour is constrained by social network membership, but this is limited to the size of the network. Impersonal exchange permits transactions to occur at a distance between parties unknown to each other. This provides a wider market for the seller and consequent cost economies from larger-scale production and increased specialization. However, impersonal exchange is founded on what North calls a credible commitment by both parties to cooperate rather than defect. Creating or adapting institutions that can foster credible commitment is thus a key aspect of modern economic development. Formal institutions associated with commercial law clearly play a role, but they would be limited in their effectiveness without the reinforcement of informal norms of behaviour that legitimize impersonal exchange. This is, perhaps, where North's third element, the enforcement mechanism, plays a key role, especially in terms of third party enforcement by an impartial and legitimate state. North concludes that the critical watershed distinguishing Western Europe's economic ascendancy from the rest of the world was the shackling of arbitrary government in Britain in 1689. This process was repeated among neighbouring nations as monarchs were forced to bargain rights in return for revenue in order to survive (North, 1981). The result was the evolution of a legitimate legal structure (including mercantile law), the growth of science and technology, and the development of military technology that facilitated European hegemony (North, 1993: 17). 
In practice, this was merely the occasion of major institutional change, which was brought to a head by a much longer period of incremental adjustment in informal institutions or value systems conducive to modern systems of exchange and production. North accounts for institutional change by a process of interaction between organizations (the players) and institutions (rules and conduct). In particular, competition among organizations is important to encourage their investment in new skills and knowledge, which in turn will shape future perceptions and belief systems.

Previous historical experience therefore plays a major role in subsequent institutional change. While North emphasizes this process as change, not necessarily progress, not all would agree entirely with his explanation of what drives institutional change. Value systems are shaped by many aspects of historical experience, both economic and non-economic in nature. Not only can institutions be socially inefficient, as North would acknowledge, neither need they be privately efficient.

Phases of institutional development in Australia

One can identify three broad phases of institutional development and change in Australia since British settlement. For much of the nineteenth century, Australian institutions were those of the British Empire, imported into Australia but insufficiently adapted to local conditions. Emerging self-determination, economic crisis in the 1890s and the move to Federated nationhood in 1901 invoked the development of distinctive national institutions, though barricaded within a siege-like mentality from international influences. The final two decades of the twentieth century witnessed a more outward-looking institutional structure, embracing multilateral relationships from a multicultural society in an era of globalization. Each 
of these institutional structures constituted a punctuation or marked shift from the previous one: colonial to national to global. This punctuation or transition from one stage to the next has been driven, to a large degree, by the tension between the existing domestic institutional structure and a changing international environment, and between changing informal belief systems and more entrenched formal institutional structures.

Colonial institutions: beneficent servants of empire

Establishment

Australia was the fortuitous importer of the institutional structure most conducive to rapid economic development. The economic hegemony achieved by Britain at the end of the eighteenth century drew heavily upon the type of institutional innovations identified by North and by Rosenberg and Birdzell. In Britain, these included a system of government that emphasized the rule of law and legitimate authority ahead of arbitrariness in behaviour and in the exercise of power. In the economic sphere, institutional innovativeness included sophisticated financial, commodity and insurance markets, accounting systems and mercantile law. An array of legal forms of business enterprise served as the vehicles for expanded production and exchange; these included the chartered and joint stock companies, the partnership, and ownership by tenants in common. The family firm was the dominant and largely successful form of ownership and management, reinforced by powerful social and economic networks of entrepreneurs. Together the family and the network reduced transaction costs and enhanced flows of information, commodities and credit. ${ }^{4}$ 
While benefiting from this legacy, there were few formal institutions in Australia during the earliest years of British settlement, and those in existence served the specific needs of a British penal colony rather than a market economy. Where formal institutions were called upon, such as legal or political representation, they were more likely to be located in London than Sydney, resulting in delays, misunderstandings and asymmetries of information. Thus, for example, when the Bank of New South Wales sought the legal status of a joint stock company, it received Governor Macquarie's agreement locally but permission from the British government was refused, leaving the Bank in the invidious position of trading as a joint stock company in organization but an unlimited liability partnership in law.

With a paucity of formal institutions, of particular interest for the early years of settlement are the informal institutions represented in belief systems and codes of conduct brought to Australia by British migrants. On the one hand, the fact that many were convicted criminals suggests that the levels of trust and credible commitment required in economic transactions may have been in short supply. Against this, it must be borne in mind that many were convicted of petty offences, often the result of desperation from abject poverty. It is doubtful that most of these convicts were part of a hardened criminal class (Nicholas, 1990; Shlomovitz, 1990). Moreover, some brought with them business experience, entrepreneurial values and trade skills (Oxley, 1996). Many came from close-knit working-class and ethnic communities, particularly in East London, where a strong emphasis was placed upon trustworthy behaviour within their group. ${ }^{5}$ Significantly, early forms of enterprise in Australia largely took the form of personal exchange, relying upon repeated dealing among small local firms as a basis for honest behaviour. Kinship and social networks added to the sense of trust (Ville, 1998). ${ }^{6}$ 
It has been suggested by Greene that British migrants carried with them to the colonies large stocks of social capital, which helped to form a European-style civil society in these nations. Moreover, the partibility, adaptability and enhancibility of social capital made it especially transferable to very different economic and social contexts (Greene, 2001). Social capital is a widely defined and used term but is best thought of as the development of shared social norms and values based on cooperation, trust, reciprocity and obligation. ${ }^{7}$ Greene adopts a very broad definition which in effect covers most institutional forms. Others have focused more closely on trust and cooperation. Macintosh's study of English communities, 1300-1640, makes a case for the development of large stocks of social capital established both through the actions of local bodies such as the church, charities and the courts, along with informal groups: kinship, friendship, co-workers and neighbourliness. The role of organizations as lubricators of cooperation has been widely discussed in the social capital literature, particularly in light of the central role attributed to them by Robert Putnam. Analyses of European medieval guilds, however, suggest they were also capable of generating divisiveness and exclusivity (Putnam, 2000; Ogilvie, 2003). While social capital carries notions of a cooperative community spirit, other writers have identified individualism as the predominant British belief system, resonating strongly with an entrepreneurial and inventive ethos. It has been widely argued that Britain made a transition from a peasant society to an individualistic and commercial one in the sixteenth and seventeenth centuries, although Macfarlane controversially argued for a much earlier genesis of English individualism. ${ }^{8}$

After about 1800, the arrival of more 'free' immigrants to Australia, many of whom were merchants from British and Indian houses, the increasing numbers of emancipated convicts ('emancipists') and a change in official attitudes towards them 
from Macquarie's governship, and pressure from London for financial self-sufficiency in the colonies, provided new opportunities for economic activity beyond the jail and out of the control of the New South Wales Corps. By the time of Commissioner Bigge's 1821 reports into the colonies, many of his recommendations were already under way including the preferred assignment of convicts to private employers and the encouragement of private investors. As Butlin has noted, a mixed economy began to take shape after 1810, comprising a conventional public sector alongside a rapidly growing private sector (Butlin, 1994: 3).

Nonetheless, for most of the nineteenth century, economic expansion remained largely under the custodianship of British institutions: Australian wool and other commodities were largely sold in London; 'colonial capital' was raised on the London Stock Exchange and managed by British boards of directors; economic policy, such as the Navigation Laws, was British; and technological innovation focused upon the needs of the industrializing British economy with a very different climate and set of factor costs from primary-producing Australia. The dominant groups ('elites') driving institutional change were British or 'Anglo-Australian', that is settlers in Australia who still considered Britain their home.

Local adaption of colonial institutions

British institutions, nonetheless, were tempered by an environment for which they were not designed. As a result, institutions evolved as they adapted to local Australian conditions, while still remaining fundamentally British and colonial. Environmental differences centred around location, climate and factor costs. Australia's location in the south Pacific made it the antipodes of Britain and remote 
from the regions of major human settlement and modern economic progress, the socalled 'tyranny of distance' thesis (Blainey, 2001). Its hot, dry climate contrasted with Britain's mild and wet one. Australia's land abundancy but labour deficiency was similarly the converse of the small but populous British Isles.

These environmental differences helped to shape the evolution of Australian belief systems in the nineteenth century, or what North calls 'mental models'. The issue of distance was not just that with the rest of the world: communications among a colony's rural settlements and, intercolonially, between the major centres of Sydney and Melbourne, was slow and unreliable. The sense of isolation of small communities added to the great uncertainty of small-scale farming in a hot, dry climate and helped to develop a strongly supportive frame of mind. With few alternative distractions and the need to share knowledge, assets, skills and experiences, communities were thrown together in a plethora of local organizations of a strongly inclusive and socially interactive nature: social and sporting clubs, charity groups, religious gatherings, agricultural and horticultural societies and farmers clubs were all to be found in most pastoral and farming districts of south-eastern Australia by the late 1850s. While this sense of community was akin to the experiences of British rural life, the additional factors of extreme isolation, limited social hierarchies and class symbols, convictism, and a predominantly male population at first, generated a greater sense of equality and mutual help as reflected in high levels of social capital and the idea of mateship.

While the church was an important institution of colonial Australian communities, the accompanying religion was more rational and secularist than in Britain, sometimes referred to as civil religion. This has been attributed to the use of religion as an ethics system in the early penal colony and the adoption of a practical and 'here-and-now' approach to life in the face of great hardships on the frontier and 
a strong sense of uncertainty. This took precedence over esoteric ideology and personal sacrifice for a hereafter life that could not easily be verified (Gillman, 1999: 239-42). Religious interdenominationalism was rarely a source of conflict in contrast to European experience. Relations between Catholics and Protestants in rural Australia, for example, were generally 'harmonious and cooperative', helped by nonextreme forms of doctrinal interpretation if not a degree of irreligiosity (Logan, 2000: 121; Swan, 1970; Jackson, 1987; Campbell, 1997).

By mid-century, cooperative behaviour was furthered by a relatively homogeneous group of settlers, educated and of medium-to-high social rank. They frequently came from the same region of Britain, shared similar cultural values and religious beliefs, and included large extended-family groupings. ${ }^{9}$ Scots, with their strong emphasis upon family and clan, were numerous. Former military officers and employees of the East India Company were also common (James, 1949: 63; Roberts, 1935: 368-75). The arrival of non-British migrants rarely engendered distrust and social dislocation. Outside the highly itinerant goldfields, European-Chinese relations were generally characterized by 'mutual cooperation and benefit'. Lancashire has noted the support of rural institutions such as the judiciary, local press and large landowners for their Chinese communities against prejudicial legislation emanating from urban central government, which may suggest some tension between local and British influences upon institutional development (Lancashire, 2000: 229, 237-8).

The adaptiveness of colonial Australia's institutions is perhaps best illustrated by the Victorian gold mining boom of the 1850s. The discovery of gold in July 1851 led to a rapid influx of diggers, with the population of the Victorian goldfields rising from 19,000 to $144,000,1851-60$. Most of the prospecting occurred on public land and, with additional concerns over social stability, the Victorian government 
introduced a system of property rights to govern mining, which included a licence fee and a defined size of claim. These rules proved defective in terms of incentives and were difficult to enforce, which, when combined with rapid changes in the technology and geology of mining, contributed to the unrest that culminated in the Eureka Stockade rebellion of 1854 . Whilst suppressing the rebellion with armed force, the Victorian government took note of the complaints and instituted major institutional reforms in the mining communities. These reforms provided more effective allocation of property rights and political representation, which secured social stability and more effective resource exploitation (La Croix, 1992).

Two environmental forces shaping the growth of formal as well as informal institutional structures before 1900 were distance and population size. Distance and poor communication between the colonies emphasized the sense of independence and with it the development of separate and distinctive institutional structures. The legacy of this has been fragmented and, arguably, therefore inefficient institutions creating a framework of federated nationhood, sustained by the particularism of individual states. Distance, combined with small population bases, has necessitated governments to champion the construction of expensive infrastructure, using their resources and taxing capability to raise funds for the purpose on the London Stock Exchange. This 'colonial socialism' has also generated a legacy of interventionism for twentiethcentury Australia (Butlin, 1959).

Both firms and markets were British-dominated in the nineteenth century. The Australian economy was heavily oriented towards the export of primary products, most notably wool, meat, dairy products, grain and gold. The main market for each of these products was in London, not Sydney or Melbourne. Wool was sold by auction at the London coffee houses before moving to a separate Wool Exchange 
in 1875 (Maughan, 1931: 73). In mid-century about 80 per cent of Australian wool was thus sold (Barnard, 1958: 47). Australian wool growers had to wait months to receive the proceeds of a sale in a distant market about which they understood little and from which price trend and other commercial information were slow to emerge. Sales were controlled by British consignors and brokers such as Dalgety and Australian Mercantile Land and Finance Company, and it was London firms in ancillary and related industries that benefited from the location of the market.

Financial markets were equally dependent upon London with the London Stock Exchange providing far greater levels of funding for the Australian colonial economies than the embryonic local exchanges, which dealt in a small number of mostly thinly traded scripts (Hall, 1963; Hall, 1968; Salsbury and Sweeney, 1988). British banks were also major providers of firm finance as were a wide range of British firms across many industries through personal networks and ongoing trading relationships. ${ }^{10}$ The 1830 s witnessed the establishment of British banks in Australia, notably the Bank of Australasia, the Union Bank and the Bank of South Australia, which were larger branch institutions channelling British investment and providing related services such as foreign exchange. Adapting to the needs of the Australian economy, many banks broke with British orthodoxy by lending on the collateral of landed property, livestock and other relatively illiquid securities (Merrett, 1997: 184). Banks and wool consignors are two important examples of a specific type of British multinational that was widely represented in nineteenth-century Australia: the free-standing company (Wilkins, 1988). Frequently, their domestic operations in Britain physically amounted to little more than a nameplate over a door in the City of London although, within the context of mid-nineteenth-century Australia, they were both very large and highly specialized. As late as 1910 seven of the leading ten 
companies operating in Australia were of this type (Ville and Merrett, 2000). The intention behind these companies was to secure natural resources and farming output needed by the industrializing British economy, although the benefits to the complementary Australian economy were also substantial, particularly in terms of inflows of entrepreneurship, knowledge, finance and technology and the outflow of pastoral and mining exports.

Firms domiciled in Australia drew mostly upon British laws dealing with economic association, notably incorporation as a joint stock company, partnership and tenancies in common. In the first half of the nineteenth century, incorporation was a special privilege achieved through a private Act of the British Parliament or the consent of its executive government, which was a lengthy and expensive process based upon unclear statutory and legal foundations. The problems experienced by the Bank of New South Wales were mentioned earlier. Incorporation provided a clearlydefined legal status, the free transferability of shares and, frequently, limited liability. In the first half of the century the first two benefits were of little value to small private businesses while the third, limited liability, was regarded with suspicion particularly in the eyes of creditors. There were only about 71 incorporations in New South Wales, 1835-51, and 14 in Melbourne by 1852. Such companies were concentrated in a few capital-intensive industries such as transport and utilities, were floated in cyclical booms by a small number of promoters, and had high failure rates (Salsbury and Sweeney, 1988: 6-7; Hall, 1968: 3).

Local incorporation laws were introduced in mid-century by the Australian colonies in largely identical form. It was the importance of free-standing multinationals that prompted this. Local laws facilitated joint flotation on the British and Australian colonial stock markets and the existence of Boards of Directors in both 
countries. However, it was the impact of the local mining boom of the 1850 s that caused Victoria to be the first colony to introduce legislation, covering mining companies in 1860 and extendingto all sectors four years later. New South Wales followed with legislation in 1861 and 1874 respectively. While the legislation drew closely upon the British in freely granting incorporation to businesses which provided the names of seven people, a memorandum of association, and were registered with the Registrar of Companies, there were some important differences. In 1853 Victoria and New South Wales broke with British tradition by introducing limited liability for partnerships, excluding banking and insurance. More significantly, in 1871 Victoria took the radical step of introducing no-liability for shareholders in mining ventures, which freed investors from the normal legal commitment to meet unpaid calls on their shares from the company or its creditors. Instead, forfeiture of the shares resulted from unpaid calls without further payment. Again New South Wales took a decade to replicate this law. This novel legislation helped to maintain the flow of investment into an industry with large capital needs but very high risks.

National institutions: self-serving insularity

Crisis, opportunity, and assertion

A major institutional shift took place around the end of the nineteenth century with the growth of local Australian institutions, which increasingly replaced those of the British Empire. No particular cause or event singularly defines this punctuated equilibrium. That informal institutions or belief systems, less susceptible to direct imperial control, had adapted and changed more than colonial formal institutions 
during the nineteenth century created a tension between these constraints on human interaction. As noted earlier, belief systems were heading in the direction of an Australian perspective on many matters, distinct from the British or even colonial perspective. It took a series of events to bring these frictions to a head.

The 1890s was a decade of crisis in Australia: a major economic downturn, the collapse of several leading financial institutions, prolonged drought conditions, and industrial relations conflict. These circumstances exerted enormous pressures on existing colonial institutions that ultimately weakened their role in Australia. British investors turned their back on many Australian companies following losses on speculative mining ventures, while the London boards of free standing companies in Australia began to understand the growing ineffectiveness of management by remote control. Strikes by shearers and maritime workers asserted the egalitarian aspirations of the Australian workforce, while colonial institutions had no solution or effective response to the drought. Accompanying the crisis, but in some respects a response to it, were new economic opportunities associated with the diversification of production and exchange: a widening range of primary produce and mining, new manufacturing, and the expansion of non-British trading partners.

Crisis and opportunity therefore revealed shortcomings in the institutional legacy from Britain, and led to a reassessment of the latter's nature and place in Australia. This turn of events would reinforce evolving Australian perspectives and attitudes to engender nationhood and foment a shift to local institutions reflecting national aspirations.

Much is often made of the impact of the First World War, especially the Gallipoli campaign, on Anglo-Australian relations and, later, that of the surrender in Singapore during World War Two. While there remained strong cultural, economic 
and political ties that made the two countries firm allies in wars throughout the twentieth century, Australia had already begun to develop multilateral political and economic relationships before 1914, including a growing trade balance with wartime foes Japan and Germany. ${ }^{11}$ These new trading relationships occurred within an environment of growing Australian self-determination in the face of the UK's traditional role as the imperial power and intermediary in Australia's economic and political relations with the rest of the world. War, however, served as a catalyst in the growth of domestic economic institutions including local markets and government policies.

Institutional shifts

One of the key institutional shifts in the economic sphere was the repatriation of commodity and capital markets from Britain back to Australia. Wool and other commodities had largely been sold in London in the mid-nineteenth century, as noted above. By the final two decades of the century, local sales were increasing in size and share of total disposals. This reflected the growing multilateralism of Australia's international economic relations. More wool, for example, was being sold to Continental European than British buyers by the 1890s, while shipping routes had similarly diversified. Less than 30 per cent of total wool exports had been sold in Australia at the beginning of the 1880s, but this grew to an average of 53 per cent in the following decade, and continued to rise sharply to 76 per cent in the first decade of the twentieth century and 93 per cent in the second (Ville, 2005: 76). During the First World War, Britain was able to acquire the whole of the Australian wool clip for its wartime needs under the Imperial Wool Purchase Scheme but this was under 
circumstances of tough Australian negotiations that resulted in highly beneficial terms for the Australian grower, as Tsokhas has shown (Tsokhas, 1990).

While repatriation of the wool market was largely the product of economic imperatives and the actions of wool brokers, changes in other primary produce markets were more closely associated with government action in response to economic uncertainty in evolving produce markets, resulting from war and depression. These included marketing boards, price support, and international commodity agreements. Kenwood has noted: 'The involvement of some ten federal and more than fifty state statutory marketing authorities ... has thus been the most prominent feature of Australian agricultural marketing since the 1920s' (Kenwood, 1995: 51). Operating over a wide range of commodities, the Boards had broad responsibilities, particularly price support, product promotion, and capital and technical assistance. As single desk authorities, they played a key part in the price stabilization ('home consumption pricing') policies of successive governments, which fixed home prices artificially high and stable on the justification of a wage-cost disadvantage. A logical third string to agricultural support was the negotiation of international commodity agreements to mitigate price fluctuations in overseas markets. Most agreements, however, were relatively short-lived with only marginal effects on prices (Kenwood, 1995: 53).

The local capital market matured rapidly in the first half of the twentieth century. The disapprobation of the London capital market in the 1890s, together with the growth opportunities provided by trade barriers, population expansion, and a diversifying economic structure were the triggers. The resulting domestic capital market was increasingly focused on the private sector and provided for most of Australia's capital formation needs through the twentieth century. Major 
improvements in the efficiency of its operations and the range of its services took place. It broadened its scope from its high-risk mining origins in the nineteenth century to a wide range of more stable but expanding industrials and quasi government stocks by the interwar period. Government's role included the assumption of note issue in 1910, the establishment of the Commonwealth Bank as a quasi central banker in 1912, and the statutory powers conferred on the Loans Council in 1929 to the fix the volume of public sector borrowing (Merrett, 1997).

More broadly, markets began to move from personal to impersonal. The personal business networks of the British Empire began to yield to impersonal trade and finance flows that traversed cultural and linguistic boundaries, for example with Japan and Germany mentioned above, and which required a credible commitment to function effectively.

Labour markets took a highly regulated character for at least the first half of the twentieth century, particularly in the form of centralized wage-fixing polices. The egalitarian ethos associated with the labour unrest of the 1890s and the associated breakdown of effective collective bargaining lay at the foundation of quasi-judicial compulsory arbitration, implemented by a Commonwealth Court and State Tribunals. The 1907 Harvester Judgement introduced the idea of the 'basic wage' or 'living wage' necessary to maintain a breadwinner, his wife and three children. Social policy and material need, therefore, determined wages rather than the nature of employment, although a 'secondary margin' took some account of training, skills, experience and the needs of particular industries. Between 1922 and 1953 quarterly cost-of-living adjustments were made to the basic wage. The link to economic policy, instead, was through the tariff and price maintenance, which, it was claimed, gave employers the resources to pay living wages. 
Support was provided to manufacturing beginning effectively with the 1908 Lyne Tariff. Infant industry arguments were proffered in the face of foreign competition in traded goods. The need for a more balanced and diverse economy and greater stability of employment and earnings were additionally invoked as justifications. Duties were raised in 1911 and 1914 before the Greene Tariff of 1921 used national defence reasons to justify further increases, taking the range of dutiable imports to 71 per cent (Kenwood, 1995: 69-70). Import quotas were also periodically introduced. Variations in protection levels were used to prosecute development policies; for example, preferential rates were used to foster a local automobile industry at the end of the Second World War (Conlon and Perkins, 2001: 115-16).

While multinationals continued to play an important role in twentieth-century Australia, the dominance of British-registered free-standing companies diminished. Of the top 25 non-financial firms domiciled in Australia in 1910, 12 were foreignregistered (all British). By 1930 this figure had declined to eight and then to three by 1952. Firms registered in New South Wales or Victoria began to take their place (Ville and Merrett, 2000). Where British multinationals remained in Australia, they faced tensions between the rights of local management and their London boards. Helped by improved communications, those firms willing to delegate substantial responsibilities to local management often gained a consequential competitive advantage. Among the major wool brokers, the slowness of the London boards of NZLMA and AMLF to relinquish tight control was reflected in their loss of market share in the first half of the twentieth century (Ville, 2000). Benefiting from early incumbency and tariff protection, many leading Australian firms began to expand nationally in the first half of the twentieth century. 
British free-standing companies were largely superseded by American multinationals that located manufacturing subsidiaries in Australia. They provided much of the technological and organizational know-how underpinning the industrial diversification of Australia, which provided a quid pro quo for the tariff protection sought by such firms.

Globalizing institutions: convergent efficiency

Declining competitiveness and fragmented federalism

The substitution of local institutions more akin to, and providing greater control over, Australia's twentieth-century development was a major step forward. It helped to provide the foundations for rapid economic growth and modernization, and appeared to be based upon a high degree of consensus and egalitarian behaviour led by actors who viewed themselves increasingly as Australian rather than AngloAustralian or British. Nonetheless, it was a 'White' Australian consciousness in which other racial groups were disadvantageously treated. Economically, it was limited in its ability to promote sustainable competitive advantages. Two factors largely explain its economic shortcomings: the creation of a high-cost, high-price economy and the failure to complete the national integration of political and economic institutions.

Protectionism and labour market regulation, while designed to diversify the economy and foster industrial harmony through justice, were primarily responsible for a cost-price structure that was not internationally competitive and reduced domestic consumer demand. Tariffs raised domestic production costs and, by mitigating foreign competition, sustained small firms and industries that were probably not competitive 
beyond an infant industry period, thus limiting resource reallocation to more promising long-term growth sectors and firms. Moreover, they encouraged competition-shy firms, including powerful multinationals attracted by the external tariff, to invest in rent-seeking political lobbying activity to maintain or even raise protection, rather than focus upon increased operational efficiencies particularly through innovation. ${ }^{12}$ Centralized wage determination, by largely ignoring economic imperatives such as skill and product differences, fostered labour markets relatively unresponsive to the needs of structural change. Finally, 'human protectionism', in other words the 'White Australia' immigration policy, shut out sources of productive low-wage workers (Brennan and Pincus, 2002: 64). In 1972 the OECD drew attention to Australia's declining competitiveness, which it particularly attributed to tariffs as high as 36 per cent. Domestically, a 1977 government White Paper and the Crawford Report in 1979 advocated a change in direction for trade and industry policies.

Australia's constitutional structure developed in a genuinely federal manner with final decisions on some policies lying at the state level. The structure provides some benefits in terms of checks and balances. On the other hand, it creates ambiguities regarding lines of responsibility and chains of accountability, and encourages power games amongst state and federal regulatory bodies with overlapping jurisdictions in areas such as industrial relations and agricultural support. However, Australia's is a fragmented federalism, where differences exist between the individual state constitutions, thus adding considerably to the complexity of federalstate government relations and, indeed, state-state government relations (Costar, 1999). The incomplete constitutional transformation is also seen by Olson as allowing institutional sclerosis to take hold in Australia and with it the capture of government policy by interest groups (Olson, 1984; Marks and Sadeghi, 1998). Incomplete 
integration can also be seen in economic institutions. Stock exchanges operated from the capital cities of each state, each with their own rules and modus operandi, the Australian Stock Exchange only coming into being in 1987. A uniform Companies Act for each state only came into existence in 1961-2. ${ }^{13}$

Deregulation and engagement

A decisive change of direction occurred from the 1970s and 1980s and, as at the beginning of the century, it was driven by changing belief systems at home and a shifting external environment. Australia's nationalist economic policies had achieved rapid economic growth but with the slowdown of global growth in the 1970s, more attention was focused on boosting efficiency and competitiveness. As we saw above, Australia's high cost structure, rent-seeking political economy and fragmented federalism had contributed to declining international competitiveness. Much blame was attached to the cosy consensus that provided powerful rent-seeking corporations protection from competition by trade barriers and price regulation in return for high wages for labour unrelated to levels of productivity.

The break with that conventional wisdom was as decisive and as widely accepted as its original introduction nearly a century beforehand. Changing belief systems evolved from a concern over Australia's declining relative position in the world economy and from an awareness of similar institutional re-evaluations occurring overseas. It was the Hawke and Keating Labour governments of the 1980s and early 1990s that made the decisive policy changes, but these largely had the bipartisan support of the coalition parties whose traditional philosophies they most closely reflected, and who continued the policies under the Howard governments from 
1996. What ensued may be summarized as the replacement of inward-looking, nationalist protection and regulation with outward deregulation and competition drawing upon multicultural values. While particularly applied to economic institutions in the present paper, these terms range broadly over social and political change, which in turn impinged upon economic performance. The ending of a 'White Australia' immigration policy, for example, was as important to more efficient labour markets as the dismantling of centralized wage fixing.

Key areas of change centred upon the institutions of labour and capital markets, trade policy and competition policy. Tariffs were progressively reduced with the effective rate of assistance declining from 35 to five per cent, 1972/3-2000/1 (Meredith and Dyster, 1999: 328). Various industrial incentives were offered, partly as a quid pro quo, to ease the transition to free trade, and as part of a change of focus towards the pursuit of efficiency and environmental responsibility. The stated intentions were the promotion of investment, exports, innovation, competitiveness and resource sustainability (Brennan \& Pincus, 2002: 75). In financial markets, foreign exchange controls were ended, the dollar was allowed to 'float', foreign banks were permitted to apply for licences to operate in Australia, and most remaining barriers between domestic and international financial markers were removed (Merrett, 1998). Labour market decentralization reduced the powers of federal arbitration tribunals and encouraged a focus upon enterprise-level negotiations and awards. This had the effect of reducing the role of central awards to a safety net for the low paid (Castles, 2002: 48-9). Labour skills were enhanced by the substantial expansion of participation in tertiary education as a result of elevating many educational institutions (CAEs) into universities and introducing a partial user-pay funding system (HECS) that could 
handle the vast increase in expenditure. In addition, greater attention was given to the fostering of skills that addressed employment needs (Cowie, 1999).

While shifts in the institutional structure governing labour, capital and trade largely involved loosening the reins of government control, competition policy headed in the opposite direction. The absence of effective competition policy until the final third of the twentieth century contributed to the uncompetitive business environment, allowing interfirm collusion to flourish. Butlin, Barnard and Pincus aptly summarized the situation: 'all the restrictive practices known to man were exploited in the Australian economy' (Butlin, Barnard, and Pincus, 1982: 125). ${ }^{14} \mathrm{~A}$ change of emphasis began with the Trade Practices Act (1967), which created the Trade Practices Court to investigate anti-competitive behaviour. Various enhancements to the policy have followed, including the introduction of a dominance test in 1977 and closer attention to merger activity as well as interfirm collusion. Since 1993 the structuralist approach of dominance has been largely replaced by a behavioural or conduct test of competition, The Australian Competition and Consumer Commission was created in 1995 with wide-ranging powers and coverage, and employs economic ideas and concepts to evaluate levels of competition (King, 2003). Competition has additionally been enhanced by removing the industry monopolies of government enterprises at both federal and state levels, by privatization, the admission of competing firms, or contracting out the right to provide particular services (Reserve Bank of Australia Bulletin, December 1997).

Associated with these shifting institutional patterns, particularly enhanced competition and domestic market maturity, has been the demise of the distinctive proprietary capitalism of early twentieth-century Australia and its replacement with more modern corporate forms, based on stronger organizational structures and more 
effective corporate strategies, which converge to a large degree with advanced forms of capitalism in other developed nations and have led large numbers of firms to reverse the institutional legacy by expanding overseas (Fleming, Merrett and Ville, 2004: 203).

Institutional change and innovation

One of the key drivers of a nation's nature and pace of economic development is innovation, particularly through the development of cost-reducing processes and the introduction of new products and services. Thus, a consequential issue arising from our broad survey of institutions and economic development in Australia is the impact the changing institutional structure has had upon the nature and rate of innovation. Secondly, generalizing about the institutional legacy from historical experience, we investigate the extent to which a distinctive national innovation system has evolved.

Imported British colonial institutions of the nineteenth century provided strong social, knowledge, financial and legal foundations for innovation. Thus, for example, the system of patents together with secure property rights helped to protect the value of rents associated with innovation. Well-founded networks provided the trust, cooperation and information exchanges that facilitate research and development activity. Imports of human and financial capital and modern forms of business organization further contributed to the munificent environment for innovative behaviour and provided access to wider international sources of information and expertise. Innovation opportunities in turn impact upon a nation's institutional structure, much of the microeconomic reform of recent decades being designed to 
increase Australia's exposure and receptiveness to overseas technology in high growth industries.

The informal institutions associated especially with mental models or belief systems supported an innovative culture. These included a mixture of social capitalstyle cooperation, sharing the diagnosis of problems and their solution, while at the same time a strong dose of individualism that drove many inventors to look at problems and their solution from a unique perspective. Indeed, the setting for much nineteenth-century inventive activity was the individual rather than the organization. The secularist, 'here and now' approach that developed in the nineteenth century suggests on the one hand a practical frame of mind associated with problem-solving, while on the other hand a limited interest in the long-term investments and improvements associated with experimental research and development.

However, the forms of innovation undertaken in Britain were rarely suited to the very different structure and composition of the Australian economy and natural environment. British free-standing companies in Australia, for example, provided financial support and sources of general management experience but only limited useful industry-specific know-how. While Britain provided access to international sources of information, it was carefully brokered, limiting multilateral communications with other nations.

The development of local institutions by the early-twentieth century promised to align the innovation effort more closely with national interests and economic development. Government support became more important, either directly or through public research bodies such as the CSIRO (1949) and its predecessor CSIR (1926) (Schedvin, 1987). The widening range of industries, particularly in manufacturing, fostered by the changed environment, enhanced the opportunity for applying new 
technologies, particularly those adapted from overseas. Australia's escape from British international intermediation provided more direct access to overseas sources of innovation. The arrival of many American manufacturing multinationals in the 1920s and 1930s provided important new sources of international technology transfer. The repatriation of decision-making in some companies and markets provided a stronger feedback mechanism and a greater focus on local needs and domestic research and development. Regulation and protection provided insulation against some forms of uncertainty for a small developing economy and thus a more conducive environment for research and development.

Against these positive aspects, however, the insularity, lack of competition and insufficient alignment of regulatory policy with economic incentives erected many barriers to innovation. For example, the disassociation of wages with labour productivity reduced the incentives for the workforce to support productivityenhancing innovations. Internal and external price support encouraged firms to focus on maintaining or advancing these policies rather than concentrate upon raising their internal efficiency. The survival of inefficient small firms and some industries denied resources to large firms in successful industries able to undertake extensive in-house research. In addition, fragmented federalism, particularly in the multiplicity of federal and state economic authorities distorted and confused the market signals and policy rules upon which effective innovation relies.

There are grounds for greater optimism about the third stage of institutional evolution over the final two or three decades of the twentieth century. The emphasis upon competition and efficiency, through deregulation and microeconomic reform, provides a much closer alignment of government, entrepreneurial and worker incentives with innovation. The returns to corporate rent-seeking, either through 
collusion with other producers or by lobbying government, have diminished, while the returns to labour, primed with higher skills and a broader ethnic mix, are much more closely aligned with the economic incentives of the industry. Not only have the returns to Olsonian distributional coalitions diminished, but the fundamental changes in mental modes and formal institutions have, perhaps, overturned the encroaching institutional sclerosis. In addition, mature and internationally integrated capital markets are better able to distinguish dynamic and innovative organizations within Australia and provide them with access to more extensive resources and support overseas. The belated emergence of modern, large-scale industrial enterprise in Australia has provided greater opportunities to absorb and adapt effectively foreign sources of technology to suit the local environment as well as enhanced domestic research and development capabilities (Fleming, Merrett, and Ville, 2004: 227-9).

Conclusion: towards a national innovation system

The adaptiveness of Australian institutions to profound environmental change over two centuries and the rapid establishment of impersonal markets suggest, overall, an institutional structure receptive to the opportunities presented by innovation. While much of this chapter has emphasized historical change in Australia's institutional structure, elements of continuity also exist - key patterns, moderated by historical experience. Such patterns or layers, by setting some distinctive ground rules, have helped to give shape and coherence to a multi-layered national framework for innovation at the beginning of the twenty-first century. These continuing facets include: surmounting the problems of geographical distance, small population size, and fragmented institutions, while harnessing the benefits of social cohesion, 
networking skills, a secularist state of mind, the influence of foreign direct investment, a richness of natural resources, the rule of law, and a mixed economy. These continuities, combined with the periodic shifts discussed here, provide the distinctive institutional legacy for the generation and reception of knowledge flows in Australia and thus the shaping of a contemporary national innovation system that is currently a subject of much discussion and analysis (Mapping Australian Science and Innovation, 2003). 
Notes

1 Exceptionally, see White (1992). Post-federation, see Henningham (1999) and Brennan and Castles (2002). Kenwood (1995) provides some good evidence, though focuses rather narrowly on economic policy and formal economic institutions.

2 Of particular importance, are North (1990), North and Weingast (1989), North (1993), Hirsch and Lounsbury (1996) and North (1999).

3 He gives the examples of the 'suq' and the caravan trade (North, 1990: 125-6).

4 There is a wide literature dealing with these ideas including: Jones and Rose, (1993), Muldrew (1998) and (Boyce and Ville, 2002; chapter 9).

$5 \quad$ For later in the nineteenth century, see Godley (1986).

6 New South Wales shipowning was said to be 'entwined in a complex set of relationships' (Hainsworth, 1971: 23).

$7 \quad$ See Ville (2004) for a recent survey of the subject.

8 For a recent assessment of the debate see French and Hoyle (2003).

$9 \quad$ Knack and Keefer (1997: 11) concluded that levels of trust tend to be higher in ethnically homogeneous communities following non-hierarchical religions, particularly Protestantism.

10 For example, see the substantial trade finance and industrial investment provided by British trader Robert Brooks in Broeze (1993: 81-90).

11 For example, see Meredith and Dyster (1999: 101), Tweedie (1994), Purcell (1981) and Perkins (1989).

12 For example, see Bell (1993: 20, 32-1, 103). 
13 A national listing of all securities commenced in 1972.

14 The Australian Industries Preservation Act of 1906 is generally viewed as having only a limited and temporary impact. For example, see Fleming and Terwiel, 1997).

\section{References}

Barnard, A. Australian Wool Market, 1840-1900 (Melbourne: Melbourne University Press, 1958).

Bell, S. Australian Manufacturing and the State. The Politics of Industry Policy in the Postwar Period (Cambridge: Cambridge University Press, 1993).

Blainey, G. The Tyranny of Distance: how distance shaped Australia's history (Sydney: Macmillan, 2001).

Boyce, G. and Ville, S. The Development of Modern Business (Basingstoke: Palgrave, 2002).

Brennan, G. and Castles, F. G. (eds), Australia Reshaped. 200 years of Institutional Transformation (Cambridge: Cambridge University Press, 2002). 
Brennan, G. and Pincus, J. ‘Australia's economic institutions', in G. Brennan and F.

G. Castles (eds), Australia Reshaped. 200 years of Institutional Transformation (Cambridge: Cambridge University Press, 2002): 53-85.

Broeze, F. Robert Brooks and the Australian Trade. Imperial Business in the Nineteenth Century (Melbourne: Melbourne University Press, 1993).

Butlin, N. G. 'Colonial socialism in Australia', in H. G. J. Aitken, (ed.), The State and Economic Growth (New York: Social Science Research Council, 1959): 26-78.

Butlin, N. G. Barnard, A. and Pincus, J. J. Government and Capitalism: Public and Private Choice in Twentieth Century Australia (St Leonards, NSW: Allen and Unwin, 1982).

Butlin, N. G. Forming a Colonial Economy, Australia 1810-1850. (Melbourne: Cambridge University Press, 1994).

Campbell, M. The Kingdom of the Ryans: the Irish in south west New South Wales, 1816-1890 (Sydney: University of New South Wales Press, 1997).

Castles, F. G. 'Australia's institutions and Australia's welfare' in G. Brennan and F.

G. Castles (eds), Australia Reshaped. 200 years of Institutional Transformation (Cambridge: Cambridge University Press, 2002): 25-52. 
Conlon, R. and Perkins, J. Wheels and Deals. The Automobile Industry in TwentiethCentury Australia (Aldershot: Ashgate, 2001).

Costar, B. 'State government', in J. Henningham (ed.), Institutions in Australian Society, second edition (Melbourne: Oxford University Press, 1999): 34-52.

Cowie, R. 'Education', in J. Henningham (ed.), Institutions in Australian Society, second edition (Melbourne: Oxford University Press, 1999): 159-83.

Fleming, G. and Terwiel, D. 'What effect did early Australian antitrust legislation have on firm behaviour? Lessons from business history', Australian Business Law Review, 27 (1) (1999): 47-56.

Fleming, G., D. Merrett and Ville, S. The Big End of Town. Big Business and Corporate Leadership in Twentieth-Century Australia (Melbourne: Cambridge University Press, 2004).

French, H. R. and Hoyle, R. W. 'English individualism refuted- and reasserted: the land market of Earls Colne (Essex), 1550-1750’, Economic History Review, 56 (4) (2003): 595-622.

Gillman, I. 'Religion', in J. Henningham (ed.), Institutions in Australian Society, second edition (Melbourne: Oxford University Press, 1999): 234-50. 
Godley, A. 'Jewish soft-loan societies in New York and London and immigrant entrepreneurship, 1880-1914', Business History, 38 (3) (1996): 101-16.

Greene, J. P. 'Social and Cultural Capital in Colonial British America: A Case Study', in R. I. Rotberg (ed.), Patterns of Social Capital: Stability and Change in Historical Perspective (New York: Cambridge University Press, 2001): 491-509.

Hainsworth, D. R. The Sydney traders. Simeon Lord and his contemporaries, 17881821 (Melbourne: Cassell Australia, 1971).

Hall, A. R. The London Capital Market and Australia, 1870-1914 (Canberra: Australian National University Press, 1963).

Hall, A. R. The Stock Exchange of Melbourne and the Victorian Economy, 1852-1900 (Canberra: Australian National University Press, 1968).

Henningham, J. (ed.), Institutions in Australian Society (Melbourne: Oxford University Press, 1999).

Hirsch, P. M. and Lounsbury, M. D. 'Rediscovering volition: the institutional economics of Douglass C. North', Academy of Management Review, 21 (3) (1996): 872-73.

Jackson, H. R. Churches and People in Australia and New Zealand, 1860-1930 (Wellington: Port Nicholson Press, 1987). 
James, G. F. (ed.) A Homestead History: The Reminiscences and Letters of Alfred Joyce of Plaistow and Norwood, Port Phillip, 1843-64 (Melbourne: Melbourne University Press 1949).

Jones G. and Rose, M. B. Family capitalism (London: F. Cass, 1993).

Kenwood, A. G. Australian Economic Institutions since Federation (Melbourne:

Oxford University Press, 1995).

King, S. P. 'Competition policy and regulation', in I. McAllister, S. Dowrick and R. Hassan (eds.), The Cambridge Handbook of Social Sciences in Australia (Cambridge: Cambridge University Press, 2003): 31-44.

Knack, S. and Keefer, P. 'Does Social Capital Have an Economic Payoff? A CrossCountry Investigation', Quarterly Journal of Economics, 112 (4) (1997): 1251-88.

La Croix, S. J. 'Property rights and institutional change during Australia's gold rush', Explorations in Economic History, 29 (2) (1992): 204-27.

Lancashire, R. 'European-Chinese Economic Interaction in a Pre-Federation Rural Australian Setting', Rural Society, 10 (2) (2000): 229-41.

Logan, J. 'Sectarianism in Ganmain: A Local Study, 1912-21', Rural Society, 10 (2) (2000): 121-38. 
Mapping Australian Science and Innovation (Canberra: Department of Education Science and Training, 2003).

Marks, A. and Sadeghi, M. 'Testing the Olson hypothesis within the Australian context', Australian Economic Review, 31 (2) (1998): 130-44.

Maughan, C. Markets of London (London: Pitman, 1931).

Meredith D. and Dyster, B. Australia in the Global Economy (New York: Cambridge University Press, 1999).

Merrett, D. T. 'Capital markets and capital formation in Australia, 1890-1945', Australian Economic History Review, 37 (3) (1997): 181-201.

Merrett, D. T. 'Capital markets and capital formation in Australia, 1945-90', Australian Economic History Review, 38 (2) (1998): 135-54.

Muldrew, C. The Economy of Obligation: the Culture of Credit and Social Relations in Early Modern England (Basingstoke: Macmillan, 1998).

Nicholas, S. 'Reinterpreting the Convict Labour market', Australian Economic History Review, 30 (2) (1990): 50-66. 
North, D. C. and Thomas, R. P. Rise of the Western World: a new economic history (Cambridge: Cambridge University Press, 1973).

North, D. C. Structure and change in economic history (New York: Norton, 1981).

North, D. C. and Weingast, B. R. 'Constitutions and commitment: the evolution of institutions governing public choice in seventeenth-century England', Journal of Economic History, 49 (4) (1989): 803-32.

North, D. C. Institutions, Institutional Change and Economic Performance (Cambridge: Cambridge University Press, 1990).

North, D. C. 'Institutions and credible commitment', Journal of Institutional and Theoretical Economics, 149 (1) (1993): 11-23.

North, D. C. Understanding the process of economic change (London: Institute of Economic Affairs for the Wincott Foundation, 1999). Occasional Paper 106.

Ogilvie, S. A Bitter Living: Women, Markets, and Social Capital in Early Modern Germany (New York: Oxford University Press, 2003).

Olson, M. Australia in the perspective of the rise and decline of nations (Canberra: Centre for Economic Policy Research, Australian National University, 1984) Discussion Paper 109. 
Oxley, D. Convict Maids: the forced migration of women to Australia (Melbourne: Cambridge University Press, 1996).

Perkins, J. 'German shipping and Australia before the First World War', Australian Economic History Review, 29 (1) (1989): 42-59.

Purcell, W. R. 'The development of Japan's trading company network in Australia, 1890-1941', Australian Economic History Review 21 (2) (1981): 114-32.

Putnam, R. D. Bowling Alone: The Collapse and Revival of American Community (New York: Simon \& Schuster, 2000).

Reserve Bank of Australia. 'Privatisation in Australia', Reserve Bank of Australia Bulletin (December 1997)

[http://www.rba.gov.au/PublicationsAndResearch/Bulletin/bu_dec97/bu_1297_2.pdf]

Roberts, S. H. The Squatting Age in Australia, 1835-47 (Melbourne: Melbourne University Press, 1935).

Rosenberg, N. and Birdzell, L. E. How the West Grew Rich. The Economic Transformation of the Industrial World (New York: Basic Books, 1986).

Salsbury, S. and Sweeney, K. The Bull, the Bear and the Kangaroo: the History of the Sydney Stock Exchange (Sydney: Allen \& Unwin, 1988). 
Schedvin, C. B. Shaping Science and Industry: a History of Australia's Council for Scientific and Industrial Research (Sydney: Allen \& Unwin, 1987).

Shlomovitz, R. 'Convict workers: a review article', Australian Economic History Review, 30 (2) (1990): 67-88.

Swan, K. A History of Wagga Wagga (Wagga: City Council, 1970).

Tsokhas, K. Markets, Money \& Empire. The Political Economy of the Australian Wool Industry (Melbourne: Melbourne University Press, 1990).

Tweedie, S. Trading Partners. Australia and Asia, 1790-1993 (Sydney: UNSW Press, 1994).

Ville, S. 'The relocation of the international market for Australian wool', Australian Economic History Review, 45 (1) (2005): 73-95.

Ville, S. 'Social capital: an insight revealed or a concept too many?', Working Papers in Economics, (University of Wollongong, 2004).

Ville, S. The Rural Entrepreneurs. A History of the Stock and Station Agent Industry in Australia and New Zealand (Melbourne: Cambridge University Press, 2000).

Ville, S. 'Business development in Colonial Australia', Australian Economic History Review, 38 (1) (1998): 16-41. 
Ville, S. and Merrett, D. T. 'The development of large scale enterprise in Australia, 1910-64', Business History, 42 (3) (2000): 13-46.

White, C. Mastering risk. Environment, markets and politics in Australian economic history (Melbourne: Oxford University Press, 1992).

Wilkins, M. 'The free-standing company 1870-1914: An important type of British foreign direct investment', Economic History Review, 2nd ser., 41 (2) (1988): 259-82. 